\title{
Multistakeholder Partnerships for the SDGs: Actors' Views on UN Metagovernance
}

\author{
(⿻i⿱乛龰)
}

Marianne Beisheim and Nils Simon

\begin{abstract}
In the 2030 Agenda for Sustainable Development, the United Nations assigned an important role to multistakeholder partnerships for implementing the Sustainable Development Goals. Since partnerships show a mixed success record, this article analyzes whether relevant actors in the UN context are inclined to translate lessons learned and the increased knowledge about partnerships' conditions for success into an improved "UN metagovernance." Criticizing the current institutional setup, most of the interviewed actors proposed that partnerships should be metagoverned by the UN through systemwide principles, rules, and procedures. There is, however, little consensus as to how that should be done. Drawing on assumptions from the literature and extensive empirical research, the article identifies patterns in actors' perspectives on the issue. KEYWORDs: multistakeholder partnerships, Sustainable Development Goals, governance.
\end{abstract}

The 2030 Agenda for SustainAble DeVelopment establishes the SEVENTEeN Sustainable Development Goals (SDGs) and calls for multistakeholder partnerships (MSPs) "that mobilize and share knowledge, expertise, technology and financial resources" to support the achievement of the SDGs "in all countries, in particular developing countries" (SDG 17.16). In that context, UN member states agreed to "encourage and promote effective public, public-private and civil society partnerships, building on the experience and resourcing strategies of partnerships" (SDG 17.17).

We define multistakeholder partnerships as institutionalized interactions between public and private actors, which aim at the provision of collective goods. ${ }^{1}$ In the past, MSPs were sometimes hailed as a silver bullet for promoting the implementation of international goals. Yet despite placing MSPs high on the agenda at the 2002 World Summit on Sustainable Development (WSSD) in Johannesburg and repeatedly thereafter, the UN did not systematically assess under what conditions its previous MSPs actually contributed to sustainable development. ${ }^{2}$ Rather, we have seen mainly the overall promotion of the concept and showcasing of success stories. ${ }^{3}$ This is problematic in light of research revealing a mixed record of MSPs' effectiveness in the past. ${ }^{4}$

This article presents our research on the perspectives of actors dealing with MSPs for sustainable development in a UN context. After asking the relevant actors about their experiences and any lessons learned, we investigate their 
proposals on how the UN should handle MSPs in the future. We analyze their suggestions for what we call the UN's metagovernance for MSPs; that is, principles, rules, and institutions that guide partnerships' conduct.

First, we revisit the academic literature that guided our empirical research. Then, we present our findings. We outline the UN institutions with responsibility over MSPs and discuss recent reform attempts in the context of the 2030 Agenda, highlighting the perspectives of various stakeholders. Finally, we discuss our results. We found that most stakeholders proposed stronger UN metagovernance, yet there was no consensus regarding the form and content. While some asked for a leading role of the UN, the majority took a more cautious approach, and yet others did not approve of a stronger UN involvement. In general, we found that attempts to improve the UN's metagovernance for partnerships were challenged by ideological controversies and turf battles as well as budgetary restraints.

\section{Analytical Framework and Methods}

While our study follows an inductive approach, our analysis of actors' perspectives is informed by propositions from the literature on: (1) reasons for partnering; (2) the effectiveness and legitimacy of MSPs; and (3) the role of metagovernance and typical problems of UN reform.

The UN General Assembly's resolution Towards Global Partnerships of 2015 outlines partnerships as "voluntary and collaborative relationships between various parties, both public and non-public, in which all participants agree to work together to achieve a common purpose or undertake a specific task and, as mutually agreed, to share risks and responsibilities, resources and benefits." ${ }^{\prime 5}$ This already points at reasons for international organizations to partner with nonstate actors. Rationalist arguments highlight the need for accessing either material resources, such as funds or technology, or immaterial resources, such as knowledge or legitimacy. The core idea is to build a win-win situation where public and private partners pool their resources and competencies to achieve common aims. Another reason to partner is to extend the legitimacy of the UN by including nonstate stakeholders. Partnering with nonstate actors, however, comes with challenges and side effects. ${ }^{6}$ Some researchers caution that engaging in MSPs may indeed help international organizations to achieve their mandate, but it can also shift them in a direction not wanted by their constituents: "Openness toward and cooperation with private actors hold the promise of strengthening the resource base and enhancing the legitimacy of UN agencies. The other side of the coin is that they run the risk of pursuing the agenda of private actors rather than that of their member states." ${ }^{\prime 7}$ A more fundamental critique sees MSPs as a neoliberal policy instrument that merely advances the interests of private business or aims at "bluewashing" (enhancing a company's reputation by using the UN logo). ${ }^{8}$ Other authors point out a range of risks and negative side effects of strong private sector involvement. These include increasing fragmentation of global governance, 
"market multilateralism," and the redesigning of public policies according to private interests rather than public needs. ${ }^{9}$ MSPs have also been seen as exemplary of wider changes in the $\mathrm{UN}$ development system and criticized as contributing to a shift toward noncore and unpredictable earmarked contributions, aiming at short-term output instead of structural transformations. ${ }^{10}$

Hence, we would expect that:

Proposition 1: Actors' views on the future UN metagovernance will be influenced by their normative assessment of partnerships and the respective nonstate partners, and by the functional value they attach to partners' resources.

Research on MSPs' effectiveness reveals mixed results. Philipp Pattberg et al. found evidence of widespread failure of MSPs to perform as initially planned. ${ }^{11} \mathrm{~A}$ recent study supports the view that MSPs have been "ad hoc, voluntary in nature and not always aligned to government's own efforts." ${ }^{2}$ Marianne Beisheim, Andrea Liese, and their research team investigated the effectiveness of twenty-one MSPs in diverse issue areas such as health, water and sanitation, food, sustainable energy, and social rights. ${ }^{13}$ They found that MSPs can successfully deliver governance services under certain conditions, such as a fit-for-purpose institutional design and good process management. In line with that, the broader literature identifies a range of relevant success factors for MSPs. ${ }^{14}$

The 2030 Agenda advocates to leave no one behind. Most partnerships, however, have been implemented in high- and middle-income countries rather than Least Developed Countries. ${ }^{15}$ In fragile contexts, MSPs struggle to achieve a broad and long-term impact. Research shows that it is the "best fit" between project design and the specific conditions in these areas that matters most for project success. ${ }^{16}$ Many projects tend to be unsustainable once funding has ended, or they fail to be successfully replicated or scaled up in other areas. ${ }^{17}$ Hence, the literature points out general limits of the partnership approach in such contexts. ${ }^{18}$

Taken together, we would expect that:

Proposition 2: Actors' views on the future UN metagovernance of MSPs will be based on their assessment of the past and potential future effectiveness of MSPs, considering also relevant success conditions, especially for MSPs in fragile contexts.

Last but not least, this article focuses on actors'perspectives on the UN's metagovernance for MSPs. We see MSPs' work as a part of the endeavors to provide transnational governance. ${ }^{19}$ Accordingly, metagovernance is defined as the "reflexive coordination and organization of the framework conditions under which governance [here through MSPs] takes place," ${ }^{20}$ or simply as the "organization of self-organization." ${ }^{21}$ Building on this, we conceptualize metagovernance as principles, rules, and institutions intended to guide MSPs' efforts to provide governance in the area of sustainable development. ${ }^{22}$ Such metagovernance may comprise efforts to better coordinate and strengthen a mix of diverse, otherwise 
fragmented, or weak governance efforts. ${ }^{23}$ Metagovernance could be embedded in forms of orchestration; ${ }^{24}$ that is, when an orchestrating entity (e.g., the $\mathrm{UN}$ ) affords intermediary actors (e.g., MSPs) material and ideational support to provide target actors with governance services.

We propose that metagovernance that builds on and institutionalizes lessons learned will render partnerships' work more effective. In a best-case scenario, metagovernance could help push governance actors toward output, outcome, and impact, pursuing transformative action. We, however, "know little about the dynamics of meta-governance, or about the relationship between governance and meta-governance. ${ }^{25}$ Hence, we seek to better understand how actors assess causal links between metagovernance and partnerships' performance. We are particularly interested in higher-order rules or metastandards that deal with the institutional design (i.e., structures and procedures) or the substance of MSPs and their work. Metagovernance activities could, for example, influence how partnerships produce their output and what kind of output they create.

In our research, we distinguish between enabling and ensuring measures of metagovernance. Enabling measures refer to those that support and promote the founding and operating of MSPs, including material support that strengthens operational capacities and ideational support such as legitimizing or endorsing activities. Ensuring measures aim at effective oversight of MSPs' conduct and validation of achievements; for example, by establishing formalized and binding rules of conduct, by reviewing performance, and by sanctioning noncompliance. Measures could also advise how MSPs should monitor their activities, thereby in turn enabling them to recognize problems and to learn and adapt accordingly. Correspondingly, metagovernance may be seen as a "reflexive and responsive process" through which "actors aim to combine, facilitate, shape and direct particular forms of governance in accordance with specific rules, procedures and standards." 26

In general, we suppose that both public and private authorities can act as metagovernors. ${ }^{27}$ Establishing UN metagovernance often requires a mandate by member states and its implementation by the UN's administrative bodies. In this context, politics matters. Member states are known to be reluctant to make decisions with budgetary implications and may expect secretariats to implement decisions with no increase or just a minimal one in the administrative budget. While secretariats are created by and dependent on member states, they nevertheless have room to interpret their mandate ${ }^{28}$ They have to deal with overlapping mandates or conflicts with other organizations that may have divergent positions and interests. The UN Secretariat can be expected to have a stronger interest in a central supervising role, whereas the secretariats of other UN entities may prefer retaining their autonomy. Positional differences can lead to competitive relationships and turf battles, or to a division of labor among the involved entities. $^{29}$

Hence, we would expect that: 
Proposition 3: Actors' views on the institutional design of a future UN metagovernance will be influenced by their position within the UN system and by domain interests.

In terms of methods, we applied a triangular approach. We conducted an analysis of relevant documents, reports, policy papers, and summaries of meetings issued inter alia by the $\mathrm{UN}$ and its agencies, nongovernmental organizations (NGOs), and others. We undertook participatory observation at the 2012 Rio+20 Partnership Forum, the negotiations on the SDGs and 2030 Agenda, the High-Level Political Forum on Sustainable Development (HLPF) in 2014-2016, the 2016 HLPF Partnership Exchange, and the 2016 UN Economic and Social Council (ECOSOC) Partnership Forum as well as two Expert Group Meetings (EGMs) in 2016. With a series of thirty-eight in-depth interviews since 2014 with partnership specialists and practitioners from different organizations within the UN system, civil society, the business sector, academia, and from MSPs themselves, we gained a nuanced picture of these actors' perspectives on lessons learned and options for metagovernance. However, since most of our interview partners indicated that they could not provide us with an official position and since for all internal meetings the Chatham House Rule applied, we are not able to attribute statements.

\section{UN Metagovernance for Multistakeholder Partnerships}

The General Assembly is the UN's principal decision-making body. Since 2000, it has passed nine resolutions called Towards Global Partnerships that provide broad principles about how to deal with MSPs throughout the UN system. They request the UN Secretary-General to regularly report on progress with implementing MSPs. The 2013 and 2015 resolutions put an emphasis on transparency, asking to "disclose the partners, contributions and matching funds for all relevant MSPs, including at the country level." 30 Our interview partners with a governmental background saw the Assembly as a well-positioned body to establish overarching principles, yet so far there seems to be little political will to develop detailed guidelines. In November 2017, the Assembly decided to defer the resolution to 2018 when member states will also discuss Secretary-General António Guterres's broader reform proposals for the UN development system.

ECOSOC is responsible for coordination among $\mathrm{UN}$ agencies and programs and was also home to the Commission on Sustainable Development (CSD) that issued overarching rules for MSPs at its eleventh session in 2003. Based on the Bali Guiding Principles, established during the preparatory process for the 2002 Johannesburg conference, Article 22 of the CSD-11 decision stated that MSPs should have an added value, be designed in a transparent and accountable manner, be consistent with national laws and international frameworks, be publicly announced, and that their lead partner should inform the involved countries about the initiation and progress of the partnership. Article 23 established 
rules for registering and monitoring of MSPs. These rules, however, were never fully implemented as there was neither political will to grant a sufficiently strong mandate nor adequate funding for an effective follow-up. ${ }^{31}$

Within the UN Department of Economic and Social Affairs (DESA) several divisions handle MSPs. The Office for ECOSOC Support and Coordination began organizing an annual special event on MSPs in 2008, which became the informal ECOSOC Partnership Forum in 2013. The office also organizes EGMs, promoting ECOSOC as "uniquely situated to review partnership initiatives or commitments as well as guidelines and principles for those partnerships in which the UN system is involved. It can also be the place for a discussion of areas requiring policy guidance, including outcomes of a genuine lessons learned exercise that would include failures." ${ }^{2}$ DESA's Division for Sustainable Development (DSD) served as the secretariat for the former CSD and its annual Partnership Fair, and for the Rio +20 Conference and its Partnership Forum. Most of our interview partners were rather disappointed about the output of all these fora in the past, ${ }^{33}$ criticizing the showcasing of alleged successes while relying too much on anecdotal evidence instead of systematic and critical evaluations, and missing the opportunity to also learn from failure. The division now supports the annual HLPF and organizes its Partnerships Exchange. It also manages the Partnerships for SDGs database. It issues an annual special report on partnerships. ${ }^{34}$

The UN Office for Partnerships (UNOP, established in 2006) is tasked with supporting partnership initiatives and strengthening systemwide coherence. It oversees the UN Fund for International Partnerships (UNFIP) that was established in 1998 as a trust fund to serve as an interface with the UN Foundation, which manages the donations from Ted Turner and others. Through Partnership Advisory and Outreach Services, UNOP staff assist non-UN institutions in dealing with UN procedures and in their design of programs and projects. During our interview, UNOP staff pointed out that the UN member states should set the agenda and UNOP can then bring potential partners together and support the building of MSPs, but that the UN cannot and should not govern MSPs. Other interview partners also stated that UNOP should concentrate on training and capacity building.

The Executive Office of the Secretary-General handles the Secretary-General's partnership activities. Former Secretary-General Ban Ki-moon launched several partnerships. "Every Woman Every Child," for example, has been praised by some interview partners for having its own Independent Accountability Panel. Others have criticized this kind of "global club governance" by a limited number of players as a major shift from the traditional practice of inclusive multilateral decisionmaking, raising concerns ranging from lack of accountability to conflict of interest. ${ }^{35}$ Another former Secretary-General, Kofi Annan, was a driving actor in the establishment of systemwide "Guidelines on Cooperation Between the United Nations and the Business Sector" in 2000, revised in 2009 and again in 2015. ${ }^{36}$ These provide general rules for UN-business relations, referring also to 
the UN Human Rights Council's "Guiding Principles on Business and Human Rights," and are amended by individually established guidelines within many $\mathrm{UN}$ agencies.

The Global Compact Office (GCO) works with business partners on implementing the ten principles of the compact (on human rights, labor, the environment, and anticorruption) and also supports the establishment of MSPs. ${ }^{37}$ The GCO attempts to build capacities, for example, through the online UN-Business Action Hub, publications, or webinars. The GCO facilitates the UN System Private Sector Focal Points meetings, thereby fostering interagency coordination on UN-business interaction. Most UN agencies and programs set up such focal points and established due diligence procedures; that is, a screening process for identifying problems with potential partners, such as violations of core UN norms. The GCO provides assistance, for example, through pooling information once an external partner has been screened. In our interviews, GCO secretariat staff confirmed that they will further build an enabling environment, by revamping the online Partnership Hub and by organizing the Focal Points Network and their own Local Networks meetings back-to-back to explore opportunities for MSPs in a more bottom-up fashion. The GCO also surveys the UN system for the SecretaryGeneral's biennial report on partnerships. The 2017 version of this report suggests adopting the GCO's ten principles as a common partnership standard and safeguard against reputational risk. ${ }^{38}$ Some member states, however, pointed out that those principles have not been intergovernmentally agreed on and that they predate the SDGs.

In 2009, an audit report of the UN Office of Internal Oversight Services (OIOS) found that a more comprehensive framework to guide, monitor, and oversee partnerships is required and that clear criteria for entering into MSPs, guidelines, and monitoring tools need to be determined ${ }^{39}$ In our interviews, (former) UN staff pointed out that there was neither political will to create strong institutions nor a mandate for a rigid follow-up after the 2002 Johannesburg conference - and that this might have been a mistake. In fact, already back in 2002, Annan proposed to establish a Partnership Office by effectively merging the GCO and UNFIP. Instead, with the creation of UNOP, the institutional overlap remained unresolved and a 2010 Joint Inspection Unit (JIU) report opted again for a merger. ${ }^{40}$

In 2013, Ban proposed the founding of a new Partnership Facility ${ }^{41}$ It was supposed to fulfill four functions: ensure accountability, integrity, and transparency; provide common partnership support services; create a partnership focal point network; and support and backstop multistakeholder initiatives. As such, it would have replaced UNOP and become the host of UNFIP and, through the envisaged office of an under-secretary-general for partnerships, it was planned to be linked to the Global Compact Office. The Secretary-General included this scheme in his proposed program budget for the biennium 2014-2015, with a total budget of $\$ 14.4$ million, most of which to be covered by extrabudgetary 
resources and allowing for a staff of twenty-three officials. ${ }^{42}$ The proposal lists a number of benchmarks, including a minimum of 110 multistakeholder partnership programs implemented through UN entities in-country and over $\$ 1.2$ billion channeled through the UN system. ${ }^{43}$ The proposal also refers to accountability and transparency of partnerships and metrics for evaluating and measuring their impacts.

Member states, however, did not approve of the new facility. By mid-2015, Ban withdrew his proposal. ${ }^{44}$ Our interview partners differed in their assessments of why it failed. Most of them noted that the politics and the process were flawed. Before proposing the facility with the budget to the Administrative and Budgetary Committee, it would have been advisable to build agreement among member states about its strategic vision and functions, structure, and (sizable) budget. Some pointed out that $\mathrm{UN}$ entities value their independence and do not want to be integrated. Others mentioned that some member states did not want the facility to be under the Secretary-General's office as they preferred a state-led institution, and some NGO representatives did not want it at all because they feared undue private sector influence. Yet other interview partners hinted at personal quarrels between those involved. Last but not least, all agreed that member states did not want to provide additional funding.

\section{Reforming UN Metagovernance in the Wake of the 2030 Agenda}

To establish a more ambitious UN metagovernance of MSPs (i.e., to introduce or adapt rules pertaining to these MSPs at the UN level) requires intergovernmental agreement. Pointing at the lack of effective overarching rules for and the failure of many MSPs, the majority of our interview partners felt that a more effective UN metagovernance would be desirable. Most agreed that reforms are necessary and past attempts have not been sufficient. While we do not yet see consensus among member states, the UN community continues to deliberate reform ideas regarding: (1) registration and reporting; (2) guidance; and (3) review.

\section{Registration and Reporting}

The outcome document of the 2012 Rio +20 conference, "The Future We Want," calls in Article 283 for an Internet-based registry for voluntary commitments, including MSPs, which "should make information about the commitments fully transparent and accessible to the public, and it should be periodically updated." DESA first published a temporary registry and upgraded this to the Partnerships for SDGs online platform and registry ahead of the 2015 UN Sustainable Development Summit, followed by an extended update in March 2016. All registered initiatives were asked to provide voluntary periodic reports on their activities. To this end, DESA provides a questionnaire along with specific, measurable, achievable, resource-based, time-bound deliveries (SMART) criteria. The new registry works with a traffic light system, indicating whether a partnership has 
handed in a progress report (green), has not done so for a year (yellow), or has not done so for two consecutive years (red). Despite these improvements, many of our interview partners were wary about the usefulness of such registries. They pointed toward the failures with the old CSD database, most importantly the lack of resources for proper maintenance and of governmental backing for tightening reporting requirements. Our interview partners hinted at the fact that member states do not want to delist nonreporting initiatives as they are eager to see high numbers.

\section{Guidance}

UN documents and our interviews have indicated that there is openness to upgrading metagovernance of MSPs, especially regarding guidance. Most participants of the 2016 EGMs and many of our interview partners agreed that the UN should develop principles and guidelines for UN-related MSPs. Some of them explicitly referred to the existing CSD-11 principles and suggested they should be revised by the General Assembly, ECOSOC, or the HLPF, or their content be used together with existing UN norms and standards to come up with new baselines and criteria. ${ }^{45}$ Other UN reform processes also pick up on the issue. In the context of the ECOSOC dialogue on the longer-term positioning of the UN development system, for example, a 2016 paper by the Independent Team of Advisers (ITA) calls for harmonized rules that are simplified and flexible, and systemwide delivery support for MSPs with standardized procedures, including a uniform framework for identifying and assessing risks as well as a systemwide review process with measurable and verifiable performance indicators. ${ }^{46}$ Similarly, the 2016 report of the Secretary-General on the Quadrennial Comprehensive Policy Review (QCPR) recommends developing "a system-wide approach to partnership that includes common principles, standards and guidelines to ensure that partnership policies and practices with all players are coherent and aligned with the values and purposes of the United Nations." 47

Several interview partners, especially those working directly with or even within the UN, pointed at the need to have intergovernmental backing and a mandate for such reforms. However, there is neither consensus among member states about the scope of reforms, nor agreement on how to best implement them. Member states are therefore looking for best practices. The 2016 EGM, for example, discussed the World Health Organization (WHO) Framework of Engagement with Non-State Actors (FENSA). This metagovernance framework was adopted by the World Health Assembly in 2016 to strengthen the WHO's engagement with NGOs, private sector entities, philanthropic foundations, and academic institutions while protecting the WHO's work from reputational risks, potential conflict of interest, and undue influence. It comprises a set of rules for four types of nonstate partners, an online register, a process for due diligence, a guide for staff, and a process and institutions for implementation. Another metagovernance framework for MSPs was established by the Small Island Developing States (SIDS). 
In September 2014, delegates set up "a partnership framework to monitor and ensure the full implementation of pledges and commitments through partnerships. ${ }^{48}$ It includes a Steering Committee, an annual partnership dialogue, and a standardized reporting template.

\section{Review}

All of our interview partners agreed that the international community should be able to distinguish successful MSPs from failures. For this, the UN needs capacities to systematically review which of these initiatives merit public support for scaling up and which should be eliminated because they are "zombie partnerships" that absorb resources without making a meaningful contribution. ${ }^{49}$ Several of our interview partners pointed out that the UN should focus on the review of UN-related MSPs only (i.e., not all registered MSPs) since the UN has limited capacities. While reviews should incentivize and reward front-runners, most interview partners wanted them to also address gaps and challenges.

Many interview partners referred to the High-Level Political Forum on Sustainable Development in this context. ${ }^{50}$ According to its mandate, the HLPF is to provide "political leadership, guidance and recommendations" and to "follow up and review progress in the implementation of sustainable development commitments." ${ }^{51}$ Resolution 67/290, moreover, stipulates that the HLPF's reviews "shall provide a platform for partnerships." 52 Since this is not further specified, there is room for interpretation. In July 2016, DESA-DSD in collaboration with UNOP organized the first Partnership Exchange (PX), a one-day event in parallel to the HLPF. The idea is to share information on SDG-related partnerships. In 2016, more than twenty-five MSPs presented their initiatives. While DESA staff stressed that this should not just be a place to showcase partnerships, there was not much critical debate. Other UN staff emphasized that it is crucial to discuss MSPs in an integrated way and not in parallel to intergovernmental meetings, as this has proven to be unhelpful in the past. Earlier reports suggested that the HLPF should be able to commission independent third-party reviews ${ }^{53}$ During our interviews, UN staff proposed established instruments as more "realistic" options such as Expert Group Meetings, Learning Centers, or an HLPF afternoon session.

Given the failure of the attempt to establish a central Partnership Facility, most of our interview partners preferred to design the HLPF's partnership platform in a decentralized fashion. Several interviewees took up the notion of the HLPF as a kind of "apex body" to discuss the results of various voluntary thematic, regional, and national reviews at an aggregate meta level. Most of our interview partners saw a need for a solid preparatory process for reviewing MSPs' contributions at the HLPF. ${ }^{54}$ Some suggested that UN entities should be asked to review "their" MSPs and report on the results. Accordingly, the General Assembly's 2016 QCPR resolution "calls upon the entities of the UN development system to share knowledge and best practices in partnership approaches with a view to 
improving transparency, coherence, due diligence, accountability and impact." 55 The Global Compact Office is seeking a mandate to compile data on UN entities' partnership activities in a new single repository and to prepare an annual systemwide report on MSPs' contributions toward the SDGs. ${ }^{56}$ The ECOSOC Bureau, seeing the primary responsibility for governmental oversight over UNled MSPs with ECOSOC, suggests that the ECOSOC Partnership Forum should review the findings of such evaluations. ${ }^{57} \mathrm{UN}$ staff suggested an extension of the ECOSOC Partnership Forum to involve more meeting days and to open it up to engage a broader range of stakeholders, also creating a "safe space" for MSPs and their partners to discuss failures and challenges.

Some of our interview partners wanted to see more focus on strengthening national-level metagovernance. Several NGO representatives supported in-country multistakeholder platforms with built-in accountability mechanisms. The NGO World Vision was the only actor among our participants that also developed specific suggestions for MSPs in fragile situations. Together with the Partnering Initiative, they recommended using national platforms to determine how MSPs need to be designed to meet the needs of the most vulnerable. ${ }^{58}$ Interview partners from within the UN Development Group pointed at the socalled Mainstreaming, Acceleration and Policy Support (MAPS) approach to foster national-level MSPs, working through the UN country teams and resident coordinators. They suggested that a harmonized format for conducting reviews of UN-based MSPs at the national level could be issued through the Chief Executives Board for Coordination, the UN Development Group's review of operational activities, or the UN resident coordinator system.

A 2015 DESA report states, "Few partnerships engage in adaptive management, and even fewer will share negative news about their work." ${ }^{59}$ Therefore, some of interview partners, largely those closer to business, preferred a platform on MSPs outside of the UN. Only then would a truly open, innovative, and critical assessment be possible, which would also allow for analyzing failure cases. For this to be successful, a representative of a member state suggested that an independent multistakeholder body should convene such a platform (endorsed by the UN), that involved stakeholders should decide about the agenda (not the UN), and that independent research institutes should participate. Results could be channeled back to the UN via a high-level panel with members serving in their personal capacity. To further incentivize a high degree of openness, another interviewee pointed out that a different perspective on failure is necessary, as an opportunity for learning and improving.

Other interview partners opted against any form of UN metagovernance. They pointed at the unwanted effects of formulating binding rules for a large number of widely differing MSPs, thus hampering innovation and flexibility. Again, these actors tended to be close to the business side. A few NGO representatives indicated that they were not interested in upgrading $\mathrm{UN}$ metagovernance because they principally disapproved of private sector involvement and MSPs. ${ }^{60}$ 
For them, MSPs were to be avoided or only a second-best option. Instead, they preferred to strengthen the government's capacities (e.g., to tax), to increase core funding for multilateral institutions, and to focus on civil society - or public sector-driven collaborations. Consequently, these NGO activists also opposed the UN Partnership Facility. Other NGOs, conversely, demanded that a strong UN metagovernance needs to be in place before launching any new MSPs. In our interviews, they stressed that this should entail a regulatory framework with strict ex ante criteria, guidelines, due diligence, and impact assessments by an impartial third entity within the UN system, thereby promoting a "clear separation within the UN between those that encourage and nurture partnerships and those that oversee them ... to avoid conflict of interest." ${ }^{\prime 61}$

\section{Conclusion: Toward a Common but Decentralized Approach?}

All of our interview partners agreed that there is a need to learn from the past and to better handle MSPs in the future. However, there was no clear vision of what an improved UN metagovernance should look like. We nevertheless found some patterns.

The majority of our interview partners stated that the UN needs an improved framework. Most opted for a balanced UN metagovernance that offers both the necessary enabling support for MSPs and the oversight mechanisms for ensuring compliance with core $\mathrm{UN}$ norms and accountability for results. While our interview partners from the business sector mostly concentrated on the former, those from NGOs tended to focus on the latter. This is in line with their normative view of MSPs and with their assessment of past benefits and risks. Moreover, UN staff and developing country representatives who depend on external resources tended to focus on enabling instruments and were hesitant to scare away partners with ensuring measures.

When asked about lessons learned and success conditions, interview partners confirmed the relevance of a bottom-up, flexible, and context-specific approach that MSPs should apply. In line with that, they suggested that UN metagovernance should not follow a top-down one-size-fits-all design. World Vision, for example, proposed using national platforms or community committees to develop MSPs in a participatory way, including local stakeholders and marginalized groups. Others suggested that the UN could play a facilitative role in these processes, helping member states to establish national platforms for forging needs-based and demand-driven MSPs. According to a 2015 report by the Secretary-General, countries are increasingly requesting facilitative services from the UN agencies, shifting their demand from the provision of direct support toward building relationships between actors from different sectors and across several levels. ${ }^{62}$ David Nabarro, former special adviser on the 2030 Agenda, stated that the UN should not attempt to run MSPs but instead support national governments in building and steering them —in a bottom-up fashion, "putting people on top." ${ }^{63}$ So far, many 
member states are not up to this task. ${ }^{64}$ Accordingly, the 2017 reform report by Secretary-General Guterres suggests that the reinvigorated resident coordinator offices should serve as "country-level hubs for system-wide partnership building" and a "one-stop shop" for support. ${ }^{65}$

Overall, regarding the institutional design and tasks of future UN metagovernance, only a few actors supported "grand design" ideas such as the Partnership Facility. There seems to be a tendency to go for a decentralized and task-sharing, yet coordinated, approach that aims at what may be institutionally and politically feasible. The Secretary-General's recent reform proposals mirror this in suggesting to revamp what is already there such as the resident coordinator offices, DESA, the Global Compact Office, and UNOP as "the UN's global gateway for partnerships." ${ }^{66}$ In 2018, a review of the present operations of UNOP is supposed to provide more clarity on its reinvigorated setup.

Beyond that, regarding actors' preferences, we see three groupings: first, some actors envisioned a strong role for the UN member states in terms of intergovernmental oversight. These actors were either generally critical of MSPs (and of business partners in particular) or saw the $\mathrm{UN}$ as a strictly state-led organization and feared reputational risks for the UN when involving private partners. They opted for UN systemwide strict and binding principles and guidelines for MSPs and for UN-business cooperation in particular. They believed that part of this should be a uniform system of due diligence throughout the UN system. While the Secretary-General's "Guidelines on a Principle-based Approach to the Cooperation Between the United Nations and the Business Sector" already call for all this, these actors insisted on setting up such a metagovernance framework intergovernmentally. There are, however, principle-agent conflicts (between member states and the UN system) and turf battles (within the UN system) about who should do what. The General Assembly could provide a broad framework with principles and guidelines (through its agenda item on Towards Global Partnerships). ECOSOC's Operational Activities Segment could serve as an accountability platform for systemwide performance in relation to the 2030 Agenda.

Second, most of our interview partners emphasized that the UN's metagovernance should more modestly focus on guidance instead of steering MSPs in a top-down fashion. They believed that the UN should be working with harmonized principles and guidelines, a systemwide support system, using a registry, reports, and reviews to identify best practices and gaps within the UN system, and supporting member states in working with MSPs. Most member states tended to opt for a "risk-managed approach as opposed to a risk-averse one," to "balance between nurturing and monitoring partnerships," and to limit reporting and bureaucracy costs. ${ }^{67}$ All actors criticized the UN's current ad hoc approach to review and learning based on anecdotal evidence. At the same time, most of our interview partners cautioned against overburdening the UN in general and the HLPF in particular, pointing at the low capacity of the UN to matchmake, orchestrate, and coordinate, monitor, and review MSPs. Nevertheless, we found 
that those member states that cover larger parts of the UN budget tended to shy away from any measures with "budgetary implications"- it is unlikely that this will improve in the near future.

Third, some interview partners criticized the UN for its politicized debates, the turf wars, and its inability to engage in open discussions about difficulties and failures. Indeed, learning from failure was repeatedly mentioned as a necessary element for improving the performance of MSPs, yet existing UN mechanisms appear to mostly result in mere showcasing of success stories. For that reason, some of those interviewees argued for establishing a multistakeholder institution outside the UN. Earlier attempts to build such private forms of metagovernance for SDG-related partnerships, however, found it difficult to obtain the necessary resources. ${ }^{68}$

With Guterres's reform proposals on the table, the debate about the UN's metagovernance for partnerships gains traction. The details on how to best implement reforms, however, remain politically contested. This also shows in the run-up to the negotiations on the 2018 "Towards Global Partnerships" resolution. ${ }^{69}$ Positions tend to be rooted in principled support or opposition to MSPs, budgetary concerns, domain interests, and turf battles - an observation in line with our initial propositions. Given this lack of consensus, the future UN metagovernance for partnerships risks lacking coherence and stringency, opening room for further critical debate about multistakeholderism. Without clear political guidance, it is hard to imagine that the UN can foster truly transformative partnerships for the SDGs.

\section{Notes}

Marianne Beisheim is a senior researcher at Stiftung Wissenschaft und Politik (SWP), the German Institute for International and Security Affairs. Her focus is on sustainable development governance. She was director of a twelve-year research project on partnerships for sustainable development and is a member of the German Federal Foreign Office's UN Political Advisory Board and UNA Germany's Research Council. Nils Simon is a senior project manager at adelphi, a Berlin-based think tank on sustainability. His focus is on global chemicals and waste governance, multistakeholder cooperation, and international institutions. Before he joined adelphi, he was a postdoctoral researcher at SWP, working in projects on partnerships for sustainable development and international environmental governance.

This article builds on research conducted by the SFB700/D1 "Partnerships for Sustainable Development" project team. Funded by the Deutsche Forschungsgemeinschaft, this project formed part of the Research Center SFB700, www.sfb-governance.de/ppp.

1. Marco Schäferhoff, Sabine Campe, and Christopher Kaan, "Transnational Publicprivate Partnerships in International Relations: Making Sense of Concepts, Research Frameworks, and Results," International Studies Review 11, no. 3 (2009): 451-474.

2. Liliana B. Andonova, "Public-private Partnerships for the Earth: Politics and Patterns of Hybrid Authority in the Multilateral System," Global Environmental Politics 10, 
no. 2 (2010): 25-53; Thomas N. Hale and Denise L. Mauzerall, "Thinking Globally and Acting Locally: Can the Johannesburg Partnerships Coordinate Action on Sustainable Development?" Journal of Environment and Development 13, no. 3 (2004): 220-239.

3. Karin Bäckstrand and Mikael Kylsäter, "Old Wine in New Bottles? The Legitimation and Delegitimation of UN Public-Private Partnerships for Sustainable Development from the Johannesburg Summit to the Rio+20 Summit," Globalizations 11, no. 3 (2014): $1-17$.

4. Marianne Beisheim and Andrea Liese, eds., Transnational Partnerships: Effectively Providing for Sustainable Development? (Houndmills: Palgrave Macmillan, 2014); Philipp Pattberg, Frank Biermann, Sander Chan, and Aysem Mert, eds., Public-private Partnerships for Sustainable Development: Emergence, Influence and Legitimacy (Cheltenham: Edward Elgar, 2012).

5. UN General Assembly, Towards Global Partnerships. A Principle-based Approach to Enhanced Cooperation Between the United Nations and All Relevant Partners, Draft Res. A/C.2/70/224 (23 February 2016), par. 2.

6. Andrea Liese, "Explaining Varying Degrees of Openness in the Food and Agriculture Organization of the United Nations (FAO), " in Christer Jönsson and Jonas Tallberg, eds., Transnational Actors in Global Governance. Patterns, Explanations and Implications (Basingstoke: Palgrave Macmillan, 2010), pp. 88-109.

7. Christer Jönsson, "International Organizations at the Moving Public-private Borderline," Global Governance 19, no. 1 (2013): 1-18, at 14.

8. Peter Utting and Ann Zammit, "United Nations-business Partnerships: Good Intentions and Contradictory Agendas," Journal of Business Ethics 90, no. 1 (2009): 3956; Daniel Berliner and Aseem Prakash, " 'Bluewashing' the Firm? Voluntary Regulations, Program Design, and Member Compliance with the United Nations Global Compact," Policy Studies Journal 43, no. 1 (2015): 115-138.

9. Benedicte Bull, Morten Boas, and Desmond McNeill, "Private Sector Influence in the Multilateral System: A Changing Structure of World Governance?" Global Governance 10, no. 4 (2004): 481-498; Benedicte Bull, "Public-private Partnerships: The United Nation Experience," in Graeme A. Hodge, Carsten Greve, and Anthony E. Boardman, eds., International Handbook on Public Private Partnerships (Cheltenham: Edward Elgar, 2010), pp. 479-497.

10. Barbara Adams and Jens Martens, "Fit for Whose Purpose? Private Funding and Corporate Influence in the United Nations" (New York: Global Policy Forum, 2015).

11. Pattberg et al., Public-private Partnerships for Sustainable Development.

12. Angela Bester, "Scoping Study on Monitoring, Review and Accountability for Development Cooperation to Support Implementation of a Post-2015 Development Agenda," paper prepared for UN Department of Economic and Social Affairs (DESA), Office for UN Economic and Social Council (ECOSOC) Support and Coordination (2015), p. 15.

13. Beisheim and Liese, Transnational Partnerships.

14. See Andrea Liese and Marianne Beisheim, "Transnational Public-private Partnerships and the Provision of Collective Goods in Developing Countries," in Thomas Risse, ed., Governance Without a State? Policies and Politics in Areas of Limited Statehood (New York: Columbia University Press, 2011), pp. 115-143; Beisheim and Liese, Transnational Partnerships; Organisation for Economic Co-operation and Development (OECD), 
"Development Co-operation Report 2015: Making Partnerships Effective Coalitions for Action" (Paris: OECD, 2015); Philipp Pattberg and Oscar Widerberg, "Transnational Multistakeholder Partnerships for Sustainable Development: Conditions for Success," Ambio 45, no. 1 (2016): 42-51; among many others.

15. Pattberg et al., Public-private Partnerships for Sustainable Development; Sander Chan and Christina Müller, "Explaining the Geographic, Thematic and Organizational Differentiation of Partnerships for Sustainable Development," in Philipp Pattberg, Frank Biermann, Sander Chan, and Aysem Mert, eds., Public-private Partnerships for Sustainable Development: Emergence, Influence and Legitimacy (Cheltenham: Edward Elgar, 2012), pp. 44-68, 50.

16. Marianne Beisheim, Hannah Janetschek, and Johanna Sarre, "What's the 'Best Fit'? Partnership Project Design and Its Influence on Effectiveness," in Marianne Beisheim and Andrea Liese, eds., Transnational Partnerships: Effectively Providing for Sustainable Development? (Houndmills: Palgrave Macmillan, 2014), pp. 161-189.

17. Andrea Liese, Hannah Janetschek, and Johanna Sarre, "Can PPPs Make It Anywhere? How Limited Statehood and Other Area Factors Influence PPP Effectiveness," in Marianne Beisheim and Andrea Liese, eds., Transnational Partnerships: Effectively Providing for Sustainable Development? (Houndmills: Palgrave Macmillan, 2014), pp. 131160 .

18. Utting and Zammit, "United Nations-business Partnerships"; Margret Thalwitz, "Limitations of Partnerships: Taking the Agenda Forward," in Daniel Low-Beer, ed., Innovative Health Partnerships: The Diplomacy of Diversity (Singapore: World Scientific, 2012), pp. 175-190.

19. Charles Roger and Peter Dauvergne, "The Rise of Transnational Governance as a Field of Study," International Studies Review 18, no. 3 (2016): 415-437.

20. Stamatios Christopoulos, Balasz Horvath, and Michael Kull, "Advancing the Governance of Cross-sectoral Policies for Sustainable Development: A Metagovernance Perspective," Public Administration and Development 32, no. 3 (2012): 305-323.

21. Bob Jessop, "The Rise of Governance and the Risks of Failure: The Case of Economic Development," International Social Science Journal 50, no. 155 (1998): 2945.

22. Marianne Beisheim and Nils Simon, "Meta-governance of Partnerships for Sustainable Development-Actors' Perspectives on How the UN Could Improve Partnerships' Governance Services in Areas of Limited Statehood," Working Paper No. 68 (Berlin: Sonderforschungsbereich 700, 2015).

23. Eva Sørensen, "Metagovernance: The Changing Role of Politicians in Processes of Democratic Governance," American Review of Public Administration 36, no. 1 (2006): 98-114.

24. Kenneth W. Abbott, Philipp Genschel, Duncan Snidal, and Bernhard Zangl, International Organizations as Orchestrators (Cambridge: Cambridge University Press, 2015).

25. Stephen Bell and Alex Park, "The Problematic Metagovernance of Networks: Water Reform in New South Wales," Journal of Public Policy 26, no. 1 (2006): 63-83, at 64.

26. Eva Sørensen and Jacob Torfing, "Making Governance Networks Effective and Democratic Through Metagovernance," Public Administration 87, no. 2 (2009): 234-258, at 245 . 
27. See also Boudewijn Derkx and Pieter Glasbergen, "Elaborating Global Private Meta-governance: An Inventory in the Realm of Voluntary Sustainability Standards," Global Environmental Change 27, no. 1 (2014): 41-50.

28. Frank Biermann and Bernd Siebenhüner, Managers of Global Change: The Influence of International Environmental Bureaucracies (Cambridge: MIT Press, 2008).

29. Thomas Gehring and Benjamin Faude, "A Theory of Emerging Order Within Institutional Complexes: How Competition Among Regulatory International Institutions Leads to Institutional Adaptation and Division of Labor," Review of International Organizations 9, no. 4 (2014): 471-498.

30. UN General Assembly, Towards Global Partnerships: A Principle-based Approach to Enhanced Cooperation Between the United Nations and All Relevant Partners, Res. A/RES/68/234 (7 February 2014); UN General Assembly, Towards Global Partnerships: A Principle-based Approach to Enhanced Cooperation Between the United Nations and All Relevant Partners, Res. A/RES/70/224 (23 February 2016).

31. Bäckstrand and Kylsäter, "Old Wine in New Bottles?"; Marianne Beisheim, "Partnerships for Sustainable Development: Why and How Rio+20 Must Improve the Framework for Multi-stakeholder Partnerships," Research Paper No. 2012/03 (Berlin: Stiftung Wissenschaft und Politik [SWP], 2012); Marianne Beisheim, "Reviewing the Post-2015 Sustainable Development Goals and Partnerships: A Proposal for a Multi-level Review at the High-Level Political Forum," Research Paper No. 2015/01 (Berlin: SW P, 2015); Hale and Mauzerall, "Thinking Globally and Acting Locally."

32. DESA, "Multi-stakeholder Partnerships on Implementing the 2030 Agenda: Improving Accountability and Transparency," Draft Summary of an Expert Group Meeting (New York: DESA, 5-6 February 2016), p. 4.

33. See also Bäckstrand and Kylsäter, "Old Wine in New Bottles?"

34. DESA, "Sustainable Development in Action: Special Report on Voluntary Multistakeholder Partnerships and Commitments for Sustainable Development" (New York: DESA, 2015).

35. Adams and Martens, "Fit for Whose Purpose?"

36. UN Global Compact, "Guidelines on a Principle-based Approach to the Cooperation Between the United Nations and the Business Sector" (New York: Global Compact, 2015).

37. Andreas Rasche, "The United Nations and Transnational Corporations: How the UN Global Compact Has Changed the Debate," in Joanne T. Lawrence and Paul W. Beamish, eds., Globally Responsible Leadership: Business According to the UN Global Compact (Thousand Oaks: Sage, 2012), pp. 33-49; Georg Kell, Anne-Marie Slaughter, and Thomas Hale, "Silent Reform Through the Global Compact," UN Chronicle 44, no. 1 (2007): 26-30; Wade Hoxtell, Domenica Preysing, and Julia Steets, "Coming of Age: UN-Private Sector Collaboration Since 2000” (New York: Global Compact, 2010).

38. UN General Assembly, "Enhanced Cooperation Between the United Nations and All Relevant Partners, In Particular the Private Sector," Report of the Secretary-General, UN Doc. A/72/310 (10 August 2017).

39. UN Office of Internal Oversight Services (OIOS), “Audit Report: Management of the United Nations Fund for International Partnerships (UNFIP)," AN2008/522/01 (New York: UN Office of International Oversight Services, 2009), p. 4. 
40. Joint Inspection Unit (JIU), "United Nations Corporate Partnerships: The Role and Functioning of the Global Compact" (Geneva: JIU of the United Nations System, 2010), p. 8.

41. UN General Assembly, "A Life of Dignity for All: Accelerating Progress Towards the Millennium Development Goals and Advancing the United Nations Development Agenda Beyond 2015," Report of the Secretary-General, UN Doc. A/68/202 (26 July 2013), par. 69.

42. UN General Assembly, "Proposed Programme Budget for the Biennium 20142015; Part I: Overall Policymaking, Direction and Coordination; Section 1: Overall Policymaking, Direction and Coordination," UN Doc. A/68/6, Sect. 1 (21 May 2013).

43. UN General Assembly: "Advisory Committee on Administrative and Budgetary Questions. First Report on the Proposed Programme Budget for the Biennium 20142015," UN Doc. A/68/7, Supplement No. 7 (15 August 2013), Table 1.2.

44. Adva Saldinger, "UN Partnership Facility Derailed," 28 May 2015, Devex, www .devex.com/news/un-partnership-facility-derailed-86251, accessed 24 April 2016.

45. Felix Dodds, "Multi-stakeholder Partnerships: Making Them Work for the Post2015 Development Agenda" (New York: DESA, 2015); Adams and Martens, "Fit for Whose Purpose?" pp. 124-125.

46. Independent Team of Advisers, "Partnerships for the UN Development System," Draft Paper (19 April 2016).

47. UN General Assembly, “Quadrennial Comprehensive Policy Review of Operational Activities for Development of the United Nations System: Recommendations. Report of the Secretary-General," UN Doc. A/71/292/Rev.1 (27 September 2016).

48. UN General Assembly, SIDS Accelerated Modalities of Action (SAMOA) Pathway, Res. A/RES/69/15 (2014), par. 101.

49. David Steven and Eric Kashambuzi, “Turning Ambition into Reality: Platforms and Partnerships for Delivering Agenda 2030" (New York: New York University, 2016).

50. See also Kenneth W. Abbott and Steven Bernstein, "The High-Level Political Forum on Sustainable Development: Orchestration by Default and Design," Global Policy 6, no. 3 (2015): 222-233.

51. UN General Assembly, Format and Organizational Aspects of the High-Level Political Forum on Sustainable Development, Res. A/Res/67/290 (23 August 2013), par. 2.

52. UN General Assembly, Res. A/Res/67/290, par. 8c.

53. Steven Bernstein, "The Role and Place of the High-Level Political Forum in Strengthening the Global Institutional Framework for Sustainable Development" (New York: DESA, 2013); Bruce Jenks and Don Tapscott, "Rethinking the United Nations for the Networked World" (Toronto: Global Solution Networks, 2014).

54. See also UN General Assembly, "Critical Milestones Towards Coherent, Efficient and Inclusive Follow-up and Review at the Global Level: Report of the SecretaryGeneral,"UN Doc. A/70/684 (15 January 2016): pars. 104-107.

55. UN General Assembly, Quadrennial Comprehensive Policy Review of Operational Activities for Development of the United Nations System, Res. A/RES/71/243 (1 February 2016), par. 22.

56. UN General Assembly, UN Doc. A/72/310, par. 60.

57. ECOSOC Bureau, "Summary/Update of the Second Phase of the ECOSOC Dialogue" (New York: ECOSOC Bureau, 18 July 2016). 
58. World Vision and the Partnering Initiative, "Delivering on the Promise: In-country Multi-stakeholder Platforms to Catalyse Collaboration and Partnerships for Agenda 2030," Policy Paper (World Vision and the Partnering Initiative, May 2016).

59. DESA, "Sustainable Development in Action," p. 25.

60. IBON International, "Enhancing the Development Effectiveness of the Post-2015 Global Partnership for Sustainable Development," Policy Brief (2015).

61. DESA, "Strengthening the Role of Member States in the Review of Multistakeholder Partnerships for Implementing the 2030 Agenda," Summary of an Expert Group Meeting (New York: DESA, 5 December 2016).

62. UN General Assembly/Economic and Social Council, "Implementation of General Assembly Resolution 67/226 on the Quadrennial Comprehensive Policy Review of Operational Activities for Development of the United Nations System: Report of the Secretary General," UN Doc. A/70/62-E/2015/4 (13 January 2015), par. 89.

63. David Nabarro, former special adviser on the 2030 Agenda, telephone conference with the authors, 9 February 2016.

64. Marianne Beisheim, Anne Ellersiek, Lukas Goltermann, and Pauline Kiamba, "Meta-governance of Partnerships for Sustainable Development: Actors' Perspectives from Kenya," Public Administration and Development 38, no. 3 (August 2018): 105-119.

65. UN General Assembly/Economic and Social Council, "Repositioning the UN Development System to Deliver on the 2030 Agenda: Our Promise for Dignity, Prosperity and Peace on a Healthy Planet," Report of the Secretary-General, UN Doc. A/72/684E/2018/7 (21 December 2017), par. 134 and 136.

66. Ibid., par. 140.

67. DESA, "Sustainable Development in Action"; DESA, "Strengthening the Role of Member States in the Review of Multi-Stakeholder Partnerships." See also Wade Hoxtell, "Multi-stakeholder Partnerships and the 2030 Agenda: Challenges and Options for Oversight at the United Nations," independent analytical paper prepared for DESA(2016).

68. Lili Mundle, Marianne Beisheim, and Lars Berger, "How Private Metagovernance Helps Standard-setting Partnerships Deliver," Sustainability Accounting, Management and Policy Journal 8, no. 5 (2017): 525-546.

69. See, for example, the comments of the UN Secretary-General and the UN System Chief Executives Board for Coordination on the report of the Joint Inspection Unit (JIU/REP/2017/8): UN General Assembly, "United Nations System: Private Sector Partnerships Arrangements in the Context of the 2030 Agenda for Sustainable Development," Note by the Secretary-General, UN Doc. A/73/186/Add.1 (19 July 2018). 